International Journal of Instruction e-ISSN: 1308-1470 • www.e-iji.net

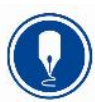

October $2018 \bullet$ Vol.11, No.4

p-ISSN: 1694-609X

pp. 901-920

Received: 01/06/2018

Revision: 30/07/2018

Accepted: 02/08/2018

\title{
Content Analysis of Theses and Articles on Ethical Leadership
}

\author{
Semra Kıranlı Güngör \\ Asst. Prof., Eskişehir Osmangazi University, Faculty of Education, Turkey, \\ semk2009@gmail.com
}

\begin{abstract}
In this study, it was aimed to examine the postgraduate theses and articles on ethical leadership in Turkey by gathering them through the document analysis method and by using content analysis. In this direction, all of the postgraduate theses and articles that can be accessed in the electronic environment as a full-text were included in the scope of the study. As a result of the research, it was determined that 96 postgraduate theses and 33 articles were conducted in Turkey from 2006-2018 (April) on ethical leadership, and the majority of the theses are master's theses. It was identified that in the research studies the quantitative method was preferred to a large extent and in the majority of them; the surveys and scales were used as data collection tools. It was determined that sampling method, sampling calculation, validity and reliability analyses were underestimated. The developed scales were used in almost all of the research studies, and similar studies with similar analysis were included in the literature. As a result, the level of contributions made by the studies conducted on ethical leadership to the literature from the scientific perspective is open to discussion.
\end{abstract}

Keywords: leadership, ethical leadership, postgraduate thesis, scientific article, qualitative analysis, content analysis.

\section{INTRODUCTION}

From the past to present, many studies were conducted on leadership. These research studies have given rise to the emergence of various theories and approaches. One of these approaches is ethical leadership. The literature of ethical leadership is a new area of research and expressed as the undiscovered aspect of leadership (Stouten, Van Dijke \& De Cremer (2012).

Ethical leadership is defined as "the demonstration of normatively appropriate conduct through personal actions and interpersonal relationships, and the promotion of such conduct to followers through two-way communication, reinforcement, and decisionmaking" (Brown, Trevino. \& Harrison, 2005, p.120). Ethical leadership is the skill of ethical decision making, integrating ethical values with the structure of the system and establishing this system. When it is considered from the perspective of individuals or organizations, ethical leadership is compatible with democracy and justice (Hermond,

Citation: Kıranlı Güngör, S. (2018). Content Analysis of Theses and Articles on Ethical Leadership. International Journal of Instruction, 11(4), 901-920. https://doi.org/10.12973/iji.2018.11457a 
2005). An ethical leader is a leader who combined moral and bureaucratic power in his/her personality and created values and belief system in terms of defining the truth (Sergiovanni, 2015).

According to Resick, Hanges, Dickson\& Mitchelson (2006, p.346), instead of defining the ethical leadership, six basic qualities of an ethical leader must be revealed. An ethical leader must be accountable, human/society oriented, fair and honest, encouraging and strengthening, motivating, ethical awareness rising. Based on these qualities, characteristics of an ethical leader can be described as follows.

Ethical leaders, always regard ethic rules in his behaviors, is always respectful towards the staff/employees and his followers, has adopted justice as a principle in his manners and behaviors, includes the subordinates in decision making processes, shares success and failure with his followers, never makes concessions regarding justice and basic rights within the company.

In other words, leaders are considered ethical as long as they display good, right, and moral behaviors. Leaders are role models for their staff and the good working atmosphere is determinant on relationships between the staff members. Behaviors of ethical leader are parallel to moral values. They value their staff, respect their rights, care about their ideas, and want them to be included in decision making processes (Zhu, May, Avolia 2004, p.11-37)

According to Thoms (2008), ethical leadership is displaying the appropriate behavior in terms of interpersonal relationships, decision making and other organizational processes. Turhan (2007, p.23) indicates that making an ethical decision is essential and explains that the decisions made by the ethical leader are the determinants of the trust in the leader. This trust forms one of the power sources of the ethical leader and named as the authentic leader. Another power source of an ethical leader is the spirit of service. This leader, which is defined as the service-oriented leader, considers himself/herself as a servant and follower before a leader. The spirit of service of the leader affects the workers of the organization and they also become workers towards service. Effective personality traits and the principles that these personality traits will infuse to followers constitute another power source of the ethical leader. This leadership form is expressed as principle-based leadership. Brown, Trevino, Harrison (2005, p.119) indicate that ethical leadership is associated with other leadership styles and features, yet none of those are sufficiently broad to include everything made by the ethical leader.

The ethical problems that emerge in every dimension of the business life, particularly the scandals occurred in banking and oil sectors in the 2000s, highlighted ethical leadership and ethical leadership has gained significance (Eisenbeiss, 2012, p.791). Thereupon, ethical leadership had drawn the attention of researchers as a research subject and research studies on ethical leadership have started to take place in the literature. In Turkey, just like the other countries in the world, the quantity of research conducted about ethical leadership has increased. However, there is no data on how this quantitative increase reflects to quality. 
It is expected from each academic study to guide the application area by providing regulatory information and contribute to the literature. This is also true for studies conducted about ethical leadership. For this purpose, identifying the aspects that are found insufficient or required to be improved by reviewing academic studies conducted on the issue has an importance. Carrying out new studies in the direction of the findings will contribute to science; otherwise, research studies that repeat each other and do not provide new findings will only overcrowd the literature and will not contribute to science. In this study, postgraduate theses and academic articles on ethical leadership, which conducted in Turkey, are examined. It is thought that this research will present the current situation of the research studies conducted on ethical leadership and contribute to the literature and application area towards its improvement.

\section{LITERATURE REVIEW}

Y1lmaz's (2006) titled “The Analysis of Organizational Trust Levels in Schools Regarding Principals' Ethical Leadership Characteristics and Various Variables" is the first study that can be accessed electronically. In this study, it was aimed to investigate the effect of school principles` ethical leadership levels on the organizational trust level in schools. As a result of the study, it was determined that organizational trust affects the sub-dimension of; sensitivity to workers, and the sub-dimensions of ethical leadership respectively, the environmental ethics, ethics in decision making and communicational ethic at a significant level.

The first article about the subject is "The impact of ethical leadership behavior on trust in manager and psychological empowerment: the mediating role of interactional justice" by Arslantaş \& Dursun (2008). The research investigates the effect of ethical leadership behavior on the trust in manager and psychological empowerment, and indirect role of interactional justice on this effect. The study was conducted in a limited company that produces knitwear and sells knitting machines. 115 blue collared employees were included in the study. According to the findings of the study, ethical leadership behavior directly supports cognitive trust. The findings also suggest that interactive justice is indirectly effective on the influence of ethical leadership behavior on emotional trust and selective and effective.

The studies conducted on ethical leadership can be examined in three main categories. The first category is the studies that examined the relationship between a variable and the ethical leader, the second is the studies that examine ethical leadership in terms of the demographics etc. characteristics of participants, and the third category is the studies that investigate the mediator and moderator roles of the ethical leader.

The studies included in the first category are the studies that investigate the relationship between ethical leadership and organizational justice (Gül \& İnce 2014; Turhan, 2007; Yıldırım, 2012) in the first place, organizational commitment (Ayık, Yücel \& Savaş, 2014; Okçu, 2014) and organizational trust (Arslantaş, 2008). In the study findings, it was identified that ethical leadership has a positive relationship with organizational justice, organizational commitment and organizational trust. In the last a few years, we see that studies conducted on ethical leadership investigate the relationship between several (more than two) variables. 
495 teachers from 36 different state schools were involved in Özdemir's (2015) study, which aimed to analyze the relationships between the teachers' emotional commitment to their schools, primary school principals' perceived social skills, their source of power and their ethical leadership behaviors. According to results of the study, a positive relationship between perceived social skills, ethical leadership, effectiveness of representation, degree of expertise, and rewarding mechanisms were found. Another finding was that, ethical leadership behaviors of school principals are as effective as their social skills on their success.

424 bank staff working at banks which are members of Turkish Banks Union was involved in Alkan \& Arıkboğa's (2017) study which analyzed the effect of organizational identification on the relationship between ethical leadership and organizational citizenship behavior. The results of the study reveal that the staffs who consider their manager as an ethical leader have a deeper feeling of commitment to their organization, and this so called felling of "unity" positively affects organizational citizenship behavior.

The studies included in the second category, the opinions of the participants concerning ethical leadership were examined in terms of demographic characteristics (Aydın, 2010; Baştuğ, 2009; Gültekin, 2008 Topuzoğlu, 2009; Y1ldız, 2016). In these studies, results that are generally compatible with each other were reached.

The studies included in the third category are the limited number of studies that were conducted in the recent years which employed more advanced levels of statistical methods and studied in the literature for the first time. The abstracts of two that draw attention among these studies were presented below.

Eroğluer \& Yılmaz (2015) conducted their study at a textile company located in İstanbul, and 166 workers were involved in the study. In their study, they investigated the effects of ethical leadership behaviors in companies, on the perceived effects of organizational climate and to what extend the feeling of isolation is influential on this case. As a result of Sobel tests and structural equation modeling made by Partial Least Squares Regression method, a positive and meaningful effect of ethical leadership behaviors was found on perceived organizational climate. It was also concluded that feeling of isolation in professional life was partly influential on these findings.

The purpose of the study conducted by Dedeoğlu, Çelik, İnanı, \& Alta (2016) is to reveal how effective the gender is on working hours in the relationship between ethical leadership organizational commitment and job satisfaction. For this purpose, a survey study was carried out with 391 participants working in hotel businesses in Antalya. As a result of the study that comprised multiple group analysis in order to examine the differentiation impact of gender and working hours, it was determined that both gender and working hours play a role on the impact of ethical leadership on organizational commitment, ethical leadership is a more important factors in terms of women's organizational commitment in comparison to men and ethical leadership is more determinative in terms of the organizational commitment of the ones who work in the business for a year or less in comparison to the ones who work for more than a year. 
Kalyar (2017) aimed to analyze the role of ethical leadership in terms of encouraging the creativity of public sector workers in Pencap region of Pakistan and increasing their work performance. In the study, the partial least squares path modeling (PLS-SEM) was employed. The results obtained revealed that ethical leadership has a direct positive and significant impact on workers performances and creativity, and an indirect impact on psychological capital, leader-member exchange (LMX) and intrinsic motivation. In the literature, any study that examines the theses and articles on ethical leadership can be found. The study is expected to contribute to the literature with this aspect.

\section{METHOD}

\section{Research Model}

This research was designed as a case study, which is a qualitative research design, and includes analysis of articles and postgraduate theses about ethical leadership. Case studies place "why" and "how" questions in the center of the research process and try to deeply explore a case or a phenomenon on which the researcher has no control (Y1ldirım \& Şimşek, 2016). In a case study, detailed description and analysis of a specified research topic in its original context is vital (Birinci, Kılıçer, Ünlüer, \& Kabakçı, 2009).

In the research study that the qualitative research model was employed, the content analysis technique was used with the purpose of examining the scope (year, type, method.) of the postgraduate theses and articles on ethical leadership that conducted in Turkey. Content analysis is an analysis method that is frequently used in social sciences. Content analysis is a "systematic, renewable technique that certain words of the text are summarized with smaller content categories through coding based on certain rules (Büyüköztürk, Çakmak, Akgün, Karadeniz ve Demirel, 2012).

\section{Population and Sample}

96 postgraduate theses and 33 articles were conducted in Turkey from 2006-2018 (April) on ethical leadership, and the majority of the theses are master's theses.

The sample of the research consists of postgraduate theses and articles written in the Turkish language on ethical leadership from 2006 to 2018 in Turkey. In the study, sampling option was not sought. All of the thesis studies written on the field of ethical leadership in the thesis database of Council of Higher Education and studies that can be accessed with the keyword of ethical leadership as a full text form from the article archive of Turkish National Academic Network and Information Center and Google academic websites were included in the scope of the study.

\section{Data Collection Tool}

In the study, document analysis method was used in the data collection process. Document analysis can be used as a data collection tool independently. Collecting the existed records and documents is called as document review (Yıldırım \& Şimşek, 2016). The document analysis method, which is also named as a documentary review, is an indispensable data collection method for almost every research study. In this sense, a documentary review includes finding sources, reading, note taking and evaluation processes towards a certain purpose (Karasar, 2014, p.183). 


\section{Research Process}

In the first phase of the content analysis, the thesis studies included in the universe were saved to the computer from the thesis database of the Council of Higher Education in pdf format. In addition, the abstracts of the restricted articles were saved. The articles examined in the study were searched on the archive of Turkish National Academic Network and Information Center (ULAKBIM) and Google academic websites by using the keyword of ethical leadership. The accessed full texts were saved to the computer and sorted out by doing the required comparisons for the reason of not choosing the same studies on both databases. Content analysis was employed in the analysis of the aforementioned theses and articles. Coding and categories are essential in terms of content analysis. The categories which are formed should be clear and the same results should be obtained when the data of the study are analyzed by another researcher (Fraenkel \& Wallen, 2005).

In this study, a coding list was created by the researcher after the purposes were determined and the literature was reviewed. Afterwards, the theses were examined and the necessary changes were made in the coding list. After receiving the expert opinion, the coding list was put into the final form.

\section{Instruments}

A form was created for the purpose of inspecting the postgraduate theses and articles on ethical leadership. There are 21 items in this form. For each article or dissertation included in the study, a row was allocated in a 21 columned form, and the studies were coded according to items. A coding list was used to fill in the form. The coding list was created after the purpose of the study was identified and related literature was reviewed. The coding list was finalized after getting expert opinion. To illustrate, if the analyzed study was an article, it was given the code 1 , if it was a dissertation it was given the code 2. All the items in the form were coded.

\section{Analysis of the Data}

It is stated that frequency and percentage are generally used in terms of the interpretation of the data obtained through content analysis (Büyüköztürk, Çakmak, Akgün, Karadeniz, \& Demirel, 2012, p.243). In the study, frequency and percentage were used among the descriptive statistical methods. The obtained data were presented in the findings section of the study as tables. The analyses were conducted on SPSS 22.0 program where the research data were transferred to.

\section{FINDINGS}

In Turkey, 96 theses were conducted and 33 articles were written on the subject of ethical leadership. The distribution of postgraduate theses and articles on ethical leadership by years was presented on Table 1 . 
Table 1

Distribution of postgraduate theses and articles on ethical leadership in Turkey by years

\begin{tabular}{lllll}
\hline Years & Theses & & Articles & \\
& $\mathrm{n}$ & $\%$ & $\mathrm{n}$ & $\%$ \\
\hline 2006 & 1 & 1.0 & 0 & 0.0 \\
2007 & 1 & 1.0 & 0 & 0.0 \\
2008 & 2 & 2.1 & 1 & 3.0 \\
2009 & 6 & 6.2 & 0 & 0.0 \\
2010 & 5 & 5.2 & 1 & 3.0 \\
2011 & 5 & 5.2 & 1 & 3.0 \\
2012 & 5 & 5.2 & 8 & 24.2 \\
2013 & 7 & 7.3 & 3 & 9.1 \\
2014 & 17 & 17.7 & 8 & 24.2 \\
2015 & 17 & 17.7 & 8 & 24.2 \\
2016 & 15 & 15.6 & 1 & 3.0 \\
2017 & 14 & 14.6 & 2 & 6.1 \\
2018 & 1 & 1.00 & 0 & 0.0 \\
Total & 96 & 100 & 33 & 100 \\
\hline
\end{tabular}

It is seen that $1(1.0 \%)$ thesis was conducted on the year of $2006,1(1.0 \%)$ on 2007,2 $(2.1 \%)$ on $2008,6(6.2 \%)$ on $2009,5(5.2 \%) 2010,5(5 . .2 \%)$ on $2011,5(5.2 \%)$ on $2012,7(7.3 \%)$ on $2013,17(17.7 \%)$ on $2014,17(17.7 \%)$ on $2015,15(15.6 \%)$ on 2016, $14(14 . .6 \%)$ on 2017 and $1(1,0 \%)$ on 2018 . When the articles written on ethical leadership are considered, it is seen that $1(3.0 \%)$ article is written on $2008,1(3.0 \%)$ on the year of $2010,1(3.0 \%)$ on $2011,8(24.2 \%)$ on $2012,3(9.1 \%)$ on $2013,8(24.2 \%)$ on 2014, $8(24.2 \%)$ on 2015, $1(3.0 \%)$ on 2016, $2(6.1 \%)$ on 2017.

Table 2

Distribution of theses and articles on ethical leadership in Turkey by institutes

\begin{tabular}{lll}
\hline Institute & Frequency $(\mathrm{n})$ & Percentage $(\%)$ \\
\hline Institute of Social Sciences & 77 & 80.2 \\
Institute of Education Sciences & 17 & 17.7 \\
Institute of Medical Sciences & 2 & 2.1 \\
Total & 96 & 100 \\
\hline
\end{tabular}

When the distribution of theses and articles on ethical leadership in Turkey by institutes given in Table 2 is considered, it is seen that $77(80.2 \%)$ of the theses and articles were written in institutes of social sciences, $17(17.7 \%)$ of them in institutes of education sciences, and $2(2.1 \%)$ of them in institutes of medical sciences. The distribution of theses and articles on ethical leadership in Turkey by the department were presented in Table 3. The similar departments were merged in terms of the distribution of the theses. 
Table 2

Distribution of Postgraduate Theses on Ethical Leadership in Turkey by Departments

\begin{tabular}{lll}
\hline Departments & Frequency $(\mathrm{n})$ & Percentage $(\%)$ \\
\hline Educational Sciences, Education Management and & 44 & 45.8 \\
Supervision, Education Management, Supervision, & & \\
Planning and Economy Departments & & \\
Business Management Department & 25 & 26.0 \\
Human Resources Management Department & 10 & 10.4 \\
Health Management Department & 4 & 4.2 \\
Physical Education and Sports Teaching, Primary & 4 & 4.2 \\
School Department & 3 & 3.1 \\
Economy Department & 2 & 2.1 \\
Political Science and Public Administration, Public & & \\
Administration Departments & 1 & 1.0 \\
Management Information Systems Department & 1 & 1.0 \\
Tourism and Hotel Management Department & 1 & 1.0 \\
Sports Management Department & 1 & 1.0 \\
Nursing Department & 96 & 100 \\
Total & &
\end{tabular}

When the departments that postgraduate theses on ethical leadership given in Table 3 are considered, it is seen that $44(45.8 \%)$ of the theses were conducted in educational sciences, education management and supervision, education management, supervision, planning and economy departments, $25(26.0 \%)$ in business management department, 10 $(10.4 \%)$ in human resources management department, $4(4.2 \%)$ in physical education and sports teaching, primary school departments, $3(3.1 \%)$ in economy department, 2 $(2.1 \%)$ in political science and public administration, public administration departments, $1(1.0 \%)$ in management information systems department, $4(4.2 \%)$ in health management department, $1(1.0 \%)$ in tourism and hotel management department, $1(1.0 \%)$ in sports management department and 1(1.0\%) in nursing department.

Table 3

Distribution of postgraduate theses on ethical leadership in Turkey

\begin{tabular}{lll}
\hline Thesis Type & Frequency $(\mathrm{n})$ & Percentage $(\%)$ \\
\hline Master's Degree & 81 & 84.40 \\
Doctoral dissertations & 15 & 15.60 \\
Total & 96 & 100 \\
\hline
\end{tabular}

When the distribution of theses and articles on ethical leadership in Turkey by types given in Table 4 is considered, it is seen that $81(84.4 \%)$ of the theses are master's theses and $15(15.6 \%)$ of them are doctoral theses.

Table 4

Distribution of postgraduate theses on ethical leadership in Turkey by allowance status

\begin{tabular}{lll}
\hline Permission Status & Frequency $(\mathrm{n})$ & Percentage $(\%)$ \\
\hline Allowed & 82 & 85.4 \\
Limited & 14 & 14.6 \\
Total & 96 & 100 \\
\hline
\end{tabular}


When the distribution of theses and articles on ethical leadership in Turkey by allowance status given in Table 5 is considered, it is seen that $82(85.4 \%)$ of the theses are allowed and $14(14.6 \%)$ are restricted.

Table 5

Distribution of postgraduate theses and articles on ethical leadership in Turkey by application area

\begin{tabular}{lllll}
\hline Application Area & Thesis & \multicolumn{3}{l}{ Article } \\
\cline { 2 - 5 } & Frequency (n) & Percentage (\%) & Frequency (n) & Percentage (\%) \\
\hline Educational Institution & 51 & 62.2 & 25 & 75.8 \\
Private Sector & 24 & 29.3 & 7 & 21.2 \\
Public Institution & 3 & 3.7 & 1 & 3.0 \\
Health Institution & & 2.4 & 0 & 0.0 \\
Public and Private sector & 2 & 2.40 & 0 & 0.0 \\
Total & 96 & 100 & 33 & 100 \\
\hline
\end{tabular}

When the distribution of theses and articles on ethical leadership in Turkey by application area given in Table 6 is considered. It is seen that 51(62.2\%) of the theses conducted in educational institutions $(62.2 \%), 24(29.3 \%)$ in public sector, $3(3.7 \%)$ in public institutions, $2(2.4 \%)$ in health institutions, 2 in $(2.4 \%)$ public and private sector, and $25(75.8 \%)$ of the articles were written in educational institutions, 7 (\%21.2) in private sector and $1(3.0 \%)$ in a public institution.

Table 6

Distribution of postgraduate theses and articles on ethical leadership in Turkey by sampling method

\begin{tabular}{lllll}
\hline Sampling Method & Thesis & & Article & \\
& Frequency (n) & Percentage (\%) & Frequency (n) & Percentage (\%) \\
\hline Specified & 46 & 56.10 & 17 & 51.5 \\
Unspecified & 27 & 32.9 & 5 & 15.2 \\
Entire Universe & 9 & 11.0 & 11 & 33.3 \\
Total & 96 & 100 & 33 & 100 \\
\hline
\end{tabular}

When the data given in Table 7 are examined and the sampling methods of the postgraduate theses on ethical leadership are considered, it is seen that in $46(56.1 \%)$ of them the sampling method was specified, in 27 (32.9\%) of them it was unspecified, and in $9(11.0 \%)$ of them the research was conducted in the entire population and for this reason the sampling method was not included. In $17(51.5 \%)$ of the articles written on ethical leadership, the sampling method was specified, in $5(15.2 \%)$ of them it was unspecified and in $11(33.3 \%)$ of them, the research was conducted in the entire population. 
Table 7

Distribution of postgraduate theses and articles on ethical leadership in Turkey by sampling calculation

\begin{tabular}{lllll}
\hline Sampling Calculation & $\begin{array}{l}\text { Thesis } \\
\text { Frequency (n) }\end{array}$ & Percentage (\%) & $\begin{array}{l}\text { Article } \\
\text { Frequency (n) }\end{array}$ & Percentage (\%) \\
\hline $\begin{array}{l}\text { Sampling Calculation } \\
\text { was Made }\end{array}$ & 48 & 58.5 & 15 & 45.5 \\
$\begin{array}{l}\text { Sampling Calculation } \\
\text { was not Made }\end{array}$ & 25 & 30.5 & 7 & 21.2 \\
$\begin{array}{l}\text { Entire Universe } \\
\text { Total }\end{array}$ & 9 & 11.0 & 11 & 33.3 \\
\hline
\end{tabular}

When the data given in Table 8 are examined and the question of whether the sampling calculation of postgraduate theses on ethical leadership are were made or not is considered, it is seen that in $48(58.5 \%)$ of them sampling calculation was not made, in $25(30.5 \%)$ of them sampling calculation was made and in $9(11.0 \%)$ of them the sampling calculation was not included due to the fact that the entire universe was taken into the research scope. In $15(45.5 \%)$ of the articles written on ethical leadership sampling calculation was not made, in $7(21.2 \%)$ of them sampling calculation was made and in $11(33.3 \%)$ of them the sampling calculation was not included due to the fact that the entire universe was taken into the research scope.

Table 8

Distribution of postgraduate theses and articles on ethical leadership in Turkey by data collection methods

\begin{tabular}{lllll}
\hline $\begin{array}{l}\text { Data Collection } \\
\text { Method }\end{array}$ & \multicolumn{2}{c}{ Thesis } & \multicolumn{2}{c}{ Article } \\
\hline Quantitative & 78 & 95.1 & 30 & 90.9 \\
Qualitative & 1 & 1.2 & 2 & 6.1 \\
Mixed & 3 & 3.7 & 1 & 3.0 \\
Total & 82 & 100 & 33 & 100 \\
\hline
\end{tabular}

According to the data given in Table 9 it is seen that in $78(95.1 \%)$ of the theses conducted on ethical leadership were collected based on the quantitative, in $1(1.2 \%)$ thesis collected based on the qualitative and in 3(3.7\%) of them the data was collected based on the mixed method. It is seen that the data in $30(\% 90.9)$ of the articles on ethical leadership were collected based on the quantitative, in $2(6.1 \%)$ articles it was collected based on the qualitative and in $1(3.0 \%)$ of them the data was collected based on the mixed method. 
Table 9

Distribution of postgraduate theses and articles on ethical leadership in Turkey by data collection tools

\begin{tabular}{lllll}
\hline Data Collection & \multicolumn{2}{c}{ Thesis } & \multicolumn{2}{c}{ Article } \\
Tools & Frequency $(\mathrm{n})$ & Percentage $(\%)$ & Frequency (n) & Percentage (\%) \\
\hline Survey or scale & 81 & 98.8 & 31 & 94.0 \\
Literature Review & 0 & 0.0 & 2 & 6.0 \\
Interview & 1 & 1.2 & 0 & 0.0 \\
Total & 82 & 100 & 33 & 100 \\
\hline
\end{tabular}

When the data presented in Table 10 are examined, it is seen that the data collection tools of the $81(98.8 \%)$ theses on ethical leadership are surveys or scales, $1(1.2 \%)$ is interview and the data collection tools for 31(94.0\%) articles are surveys or scales and for $2(6.0 \%)$ of them it is the literature review method.

Table 10

Distribution of postgraduate theses and articles on ethical leadership in Turkey by validity and reliability analyses status

\begin{tabular}{lllll}
\hline Reliability & \multicolumn{2}{c}{ Thesis } & \multicolumn{2}{c}{ Article } \\
Analysis & Frequency (n) & Percentage (\%) & Frequency (n) & Percentage (\%) \\
\hline Made & 65 & 79.3 & 13 & 41.9 \\
Not Made & 17 & 20.7 & 18 & 58.1 \\
Total & 82 & 100 & 33 & 100 \\
Validity Analysis & & & & \\
Made & 40 & 48.8 & 7 & 22.6 \\
Not Made & 42 & 5.2 & 24 & 77.4 \\
Total & 82 & 100 & 33 & 100 \\
\hline
\end{tabular}

When the reliability analysis status of the studies on ethical leadership presented in Table 11 are examined. It is seen that in $65(79.3 \%)$ of the theses the reliability analysis was made, in $17(20.7 \%)$ of them it was not made; in $13(41.9 \%)$ of the articles the reliability analysis was made and in $18(58.1 \%)$ of them it was not made. When the validity analysis status are examined, it is seen that in $40(48.8 \%)$ of the theses the validity analysis was made, in $42(51.2 \%)$ of them it was not made and in $7(22.6 \%)$ articles the validity analysis was made and in $24(77.4 \%)$ of them it was not made. In Turkey, only 1 thesis was conducted and 2 articles were written qualitatively on ethical leadership. The qualitative studies were excluded and only the quantitative studies were used as a base due to the fact that the answers to the following research questions are not included in qualitative studies.

Table 11

Distribution of postgraduate theses and articles on ethical leadership in Turkey by scale types

\begin{tabular}{lllll}
\hline \multirow{2}{*}{$\begin{array}{l}\text { Qualitative Scale } \\
\text { Type }\end{array}$} & \multicolumn{2}{c}{ Thesis } & \multicolumn{2}{c}{ Article } \\
\cline { 2 - 5 } & Frequency (n) & Percentage (\%) & Frequency (n) & Percentage (\%) \\
\hline $\begin{array}{l}\text { Developed Scale } \\
\begin{array}{l}\text { Scale Prepared by } \\
\text { the Researcher }\end{array}\end{array}$ & 79 & 97.5 & 31 & 100.0 \\
Total & 81 & 2.5 & 0 & 0,0 \\
\end{tabular}


When the data given in Table 12 are examined, it is seen that $79(97.5 \%)$ of the scales used in the postgraduate theses conducted on ethical leadership are developed scales, 2 $(2.5 \%)$ of them are the scales prepared by the researcher and when the articles are examined, it is seen that $31(100.0 \%)$ of them are developed scales.

Table 12

Distribution of postgraduate theses and articles on ethical leadership in Turkey by the owners of the scales

\begin{tabular}{lllll}
\hline \multirow{2}{*}{ Qualitative Scale Owner } & \multicolumn{2}{c}{ Thesis } & \multicolumn{2}{c}{ Article } \\
\cline { 2 - 5 } & $\begin{array}{l}\text { Frequency } \\
(\mathrm{n})\end{array}$ & $\begin{array}{l}\text { Percentage } \\
(\%)\end{array}$ & Frequency (n) & $\begin{array}{l}\text { Percentage } \\
(\%)\end{array}$ \\
\hline Y1lmaz 2005 and Y1lmaz 2006 & 34 & 42.0 & 18 & 58.1 \\
Brown et al., 2005 & 33 & 40.7 & 7 & 22.6 \\
Turhan, 2007 & 7 & 8.6 & 0 & 0.0 \\
Unspecified & 2 & 2.5 & 0 & 0.0 \\
De Hoogh and Den Hartog, & 1 & 1.2 & 1 & 3.2 \\
2008 & & & & \\
Yukl et al., 2013 & 1 & 1.2 & 0 & 0.0 \\
Uğurlu, 2009 & 1 & 1.2 & 3 & 9.7 \\
Strang, 2004 & 1 & 1.2 & 0 & 0.0 \\
Şentürk, 2014 & 1 & 1,2 & 0 & 3.0 \\
Şimşek and Altınkurt, 2009 & 0 & 0.0 & 1 & 3.2 \\
Pehlivan, 1999 & 0 & 0.0 & 1 & 100 \\
Total & 81 & 100 & 31 & \\
\hline
\end{tabular}

When the data presented in Table 13 are examined, it is seen that $34(42.0 \%)$ of the thesis studies conducted on ethical leadership used the scales prepared by Y1lmaz (2005) and Yilmaz (2006), 33 (40.7\%) of them by Brown et al., 7 (8.6\%) of them by Turhan (2007), 2 (2.5\%) of them were unspecified, 1 (1.2\%) of them by Hoogh and Den Hartog (2008), 1 (1.2\%) of them by Yukl et al., (2013), 1 (1..2\%) of them by Uğurlu (2009) 1 (1.2\%) of them by Strang (2004), 1 of them by (1.2\%) Şentürk (2014). When the articles are examined, it is seen that $18(58.1 \%)$ of the articles used the scales prepared by Yilmaz (2005) and Yilmaz (2006), 7 (22.6\%) of them by Brown et al. (2005), 1 (3.2\%) of them by de Hoogh and Den Hartog (2008), 3 (9.7\%) of them by Uğurlu (2009), 1 of them by (3.2\%) Şimşek and Altınkurt (2009), and 1 (3.2\%) of them by Pehlivan (1999).

Table 13

Distribution of the statistical methods used in postgraduate theses and articles on ethical leadership in Turkey

\begin{tabular}{lllll}
\hline Statistical Method & \multicolumn{2}{c}{ Thesis } & \multicolumn{2}{c}{ Article } \\
& Frequency & Percentage (\%) & Frequency & Percentage $(\%)$ \\
& $(\mathrm{n})$ & & $(\mathrm{n})$ & \\
\hline Definitional and Technical & 81 & 100,0 & 31 & 93,9 \\
Definitional & 0 & 0,0 & 2 & 6,10 \\
& 81 & 100 & & 100 \\
\hline
\end{tabular}


When the statistical methods used in postgraduate theses conducted on ethical leadership given in Table 14 are examined, it is seen that all $100 \%$ theses used definitional and technical statistical methods, and the definitional and technical statistical methods were used in 31(93.9\%) articles and definitional statistical methods, was used in $2(6.1 \%)$ of them.

Table 14

Distribution of the contents of the statistical methods used in postgraduate theses and articles on ethical leadership in Turkey

\begin{tabular}{lllll}
\hline \multirow{2}{*}{$\begin{array}{l}\text { Content of the Statistical } \\
\text { Methods }\end{array}$} & \multicolumn{2}{c}{ Thesis } & \multicolumn{2}{c}{ Article } \\
\cline { 2 - 5 } & $\begin{array}{l}\text { Frequency } \\
(\mathrm{n})\end{array}$ & $\begin{array}{l}\text { Percentage } \\
(\%)\end{array}$ & $\begin{array}{l}\text { Frequency } \\
(\mathrm{n})\end{array}$ & $\begin{array}{l}\text { Percentage } \\
(\%)\end{array}$ \\
\hline Difference and Relationship & 42 & 51.9 & 9 & 29.0 \\
Relationship & 20 & 24.7 & 12 & 38.7 \\
Difference Test & 12 & 14.8 & 7 & 22.6 \\
High-Level Statistic & 7 & 8.6 & 3 & 9.7 \\
Total & 81 & 100 & 31 & 100 \\
\hline
\end{tabular}

When the content of the statistical methods used in studies conducted on ethical leadership presented in Table 15 are examined, it is seen that $42(51.9 \%)$ of the theses used a difference and relationship test, $20(24.7 \%)$ of them used a relationship test, 12 $(14.8 \%)$ of them used a difference test, and 7 (8.6\%) of them used high-level statistics (structural equation, path analysis, confirmatory factor analysis). It is also seen that 9 $(29.0 \%)$ of the articles used difference and relationship test, $12(38.7 \%)$ of the articles used a relationship test, $7(22.6 \%)$ of them used a difference test and $3(9.7 \%)$ of them used high-level statistics.

\section{DISCUSSION}

The subject of ethical leadership is at the same level with the world countries and it is a relatively new area of research in Turkey. When theses which are registered on the database of the Council of Higher Education were examined, it was determined that the first study on the subject was conducted on the year of 2006 and the first academic article was written on 2008. Between the years of 2006 and 2018, 96 postgraduate theses and 33 articles in the electronic environment, 129 academic studies in total, were carried out. The year that the most articles were written are the as follows: 2012, 2014 and 2015 with 8 articles. The most theses were written on the year 2014 and 2015 with 17 postgraduate theses. As it can be seen from the data, the subject of ethical leadership has drawn a great attention as a research subject.

It was identified in the study that majority of the 96 theses written on ethical leadership were conducted in Bahçeşehir University (10 theses) and social sciences institutes (77 theses) and in educational science departments (44 theses). The topic of leadership also falls into the area of various disciplines particularly as management organization and organizational behavior. However, the phenomenon of leadership which is existed in every aspect of life in practice has also become a research subject in health institutes and in various departments from time to time as much as in social sciences institutes. This result indicates that ethical leadership has a wide range of use. 
When the postgraduate studies are examined in terms of their types, it was determined that $84.40 \%$ of them are master's thesis and $15.60 \%$ of them are doctoral theses. It is directly proportionate to the number of doctoral theses carried out in universities and can be regarded as an indicator of the fact that more doctoral theses are required on the issue. Among 96 theses conducted on ethical leadership, 82 of them are open to access and 14 of them are restricted. There are no unauthorized theses on the subject. All of the theses are located in the thesis database of the Council of Higher Education due to the fact that the history of the subject is current. The restriction option that is provided only for researchers was preferred in the latest theses. Due to the fact that these theses could not be examined, no information could be obtained on their properties and therefore it is not possible to make interpretations.

The main application area of the theses on ethical leadership is the school workers. The majority of the postgraduate theses $(62,20 \%)$ and articles $(75,80 \%)$ were conducted on school workers. It can be said the main reason of choosing school workers as the application area is the fact that educational sector workers choose the schools they work as application areas as they are more in number in postgraduate education. The fact that $45.8 \%$ of the theses are carried out in departments associated with educational sciences also supports this finding.

The samples of the scientific studies are as important as the application areas. It is required to carry out a sample method and sample calculation in terms of identifying in which extent the study results represents the universe and making generalizations. However, when the research studies on ethical leadership are considered, $11 \%$ of the theses and $33.50 \%$ of the articles tried to reach the entire universe and in $32.9 \%$ of the theses and $15.20 \%$ of the sampling method was not specified. When the situation is regarded from the aspect of sampling calculation, it was determined that sampling calculation was not made in $58.5 \%$ of the theses and $45.5 \%$ of articles. However, the sampling calculation should be definitely made to identify the representation power of the universe. This issue has emerged as a serious scientific research problem.

Almost all of the studies on ethical leadership were conducted through the quantitative method. There are one thesis and two articles that were conducted by using the qualitative method. In three theses and one article, the mixed method in which the qualitative and quantitative methods are combined was preferred. In the studies included in the literature that examine research studies on diverse issues, it was determined that the quantitative method is the most preferred method (Akyol \&Akçay, 2015; Akyol \& Yavuzkurt, 2016; Kütükçü, 2017). It is thought that the main reason for preferring the quantitative method is the fact that data can be collected through developed scales and that the qualitative method is more time-consuming and requires more effort. Thus, Varışoğlu, Şahin \& Göktaş (2013) stated that the reason for conducting a limited number of qualitative researches arises from the avoidance of researchers from spending time and effort. Indeed, it was determined that almost all of the studies preferred surveys and scales as data collection tools. In other studies examined articles and theses in diverse fields, it was also determined that surveys and scales were preferred as data collection tools at most (Akyol \& Akçay, 2015; Akyol \& Yavuzkurt, 2016; Balcı \& 
Apaydın, 2009; İşçi, 2013, Karadağ, 2009; Kütükçü, 2017; Uysal, 2013). (first written by years, now written alphabetically)

The contribution of research findings can be provided through the validity and reliability of the research. For this reason, validity and reliability analyses are applied to data collection tools used in the research. However, when the research studies on ethical leadership are taken into the consideration, it can be said that the importance of the issue is not completely understood. It is seen that the reliability analysis was not made in $20.7 \%$ of the theses $58.1 \%$ of the articles and validity analysis was not made in $51,20 \%$ of the theses and $77.4 \%$ of the articles. This situation brings the question of what kind of results the literature on ethical leadership provides and contributes to the science. Stevenson (2000) and Onwuegbuzie (2002) emphasize that this problem in the scientific research studies is also an international problem. Goodwin \& Goodwin (1985) highlight that no information was given in 52\% of the articles on reliability and in $\% 17$ of them on validity, and this situation reduces the reliability and validity of studies and usefulness of the studies. İşçi (2013) determined in the study that investigates the theses on education management that in $44,2 \%$ of the theses the validity analysis and in $28 \%$ of them the reliability analysis was not made.

The lack of ability to display a scientific approach and taking the easy way out have appeared in the research studies on ethical leadership. The developed scales were used in all of the articles written on the subject and only in two theses studies the scale that is developed by the researcher was employed. Certainly, this data does not include the 14 restricted theses which were conducted recently. When these theses are open to the access, the situation in the recent theses can be seen through an examination. It was identified that the most preferred scales in the theses on ethical leadership were the scales developed by Yilmaz (2005) and Brown, Trevino \& Harrison (2005). It is that the main reason that these scales are employed is the fact that Brown et al. have made a start of studies on ethical leadership, the scale was translated to Turkish and the form is accessible; on the other hand, the scale developed by Y1lmaz (2005) is both in Turkish, accessible and easy to apply. In other respects, the underlying reasons of using developed scales can be given as not felling the need of applying validity and reliability analysis for surveys, using the existed validity and reliability results and re-use the applied statistical methods, etc. In the circumstances, many studies which are similar to each other and do not have the characteristics of a scientific research took a place in the literature.

In almost all of the research studies the definitional and technical analysis were preferred, in more than half of the research studies difference and relationship tests were used together and in the majority $(38.7 \%)$ of the articles, the relationship tests were preferred. It is obvious that similar statistical methods were used in the studies which are alike and employed the same scales. While the relationship tests are employed in relational research studies that use more than one scale, difference tests, which enable to examine the differentiation status of ethical leadership according to the demographic characteristics of the participants, employed in studies that the ethical leadership is chosen as a research subject. Due to the fact that these studies are more comprehensive 
in comparison to articles, difference tests that examine both the relationship between two subjects and differentiation that occur according to demographic characteristics are used together. By this way, theses are increased in volume and more subjects are examined. Balcı \&Apaydın (2009) indicated in their study, which examined the status of the education management studies in Turkey that the statistical methods which were used in studies have remained at a basic level. In the study, the mediator and moderator roles of the ethical leadership were investigated by using high-level statistical methods in the limited number of studies. Theses studies present more diverse and newer findings in comparison to others. It is also thought that the increase in the number of these studies has an importance in terms of the quality.

\section{CONCLUSION}

In this study, which investigated the postgraduate theses and articles about ethical leadership, it was found that the first postgraduate dissertation was defended in 2006, and the first article was published in 2008. $80.2 \%$ of all postgraduate theses about ethical leadership were prepared at institutes of social sciences. Administration department with a percentage of $56.0,45,8 \%$ of all postgraduate theses about ethical leadership were prepared at departments related to education. Human resources department with a percentage of $40.4 \%$ follows it respectively. $85.8 \%$ of all theses about ethical leadership are at MA level, and $15.6 \%$ are at PHD level.85.4\% of all theses about ethical leadership are accessible at the database of Council of Higher Education while $15.6 \%$ of them are inaccessible. Majority of postgraduate theses and articles about ethical leadership had their samples from education field. In $11 \%$ of all theses about ethical leadership, the whole population was involved in the study; in $56.1 \%$ of them there was a sampling. When it comes to articles, in $33 \%$ of all articles the whole population was involved; in 45.5 of them there was a sampling.

Almost all of the studies about ethical leadership were conducted using quantitative methods. In all postgraduate theses and $96 \%$ of articles, data collection tools were questionnaires or scales; $6 \%$ of the articles included literature review.79.3\% of theses had reliability analysis and $48.8 \%$ of them had validity analysis; for the articles, these rates are $41.9 \%$ for reliability analysis and $22.6 \%$ for validity analysis. In only $2.5 \%$ of theses a scale developed by the writer were utilized, in the others an existing scale was utilized. The scale prepared by Yilmaz (2005) and Yilmaz (2006) was the most frequently used one followed by that of Brown et.al (2005). In $6.1 \%$ of the articles about ethical leadership descriptive statistics were used; the rest of the articles and theses utilized both descriptive and predictive statistics. Theses that use statistical methods mostly used variance and correlation tests (51.9\%). In articles correlation tests were most favored (38.7\%). More complex statistics were used in $86 \%$ of the theses and $9.7 \%$ of the articles. The purpose of this study was to examine the postgraduate thesis and the articles about ethical leadership below is the discussion of the findings.

\section{SUGGESTIONS}

Studies about leadership are not high in quantity. This is a sign that MA level studies about the subject are more common. If the number of $\mathrm{PhD}$ level studies increase, the 
field will become more diversified. Based on the finding that the majority of the studies were made using quantitative methods, carrying out studies using qualitative methods is another suggestion. Reliability and validity analyses were not very common about the studies on ethical leadership. In order to reach better standards about the studies, these issues must be given more importance. New data collection tools must be developed. Mixed method studies that help gathering more data can be utilized.

\section{REFERENCES}

Akyol, B. \& Yavuzkurt, T. (2016). Türkiye'de lisansüstü tezlerde eğitim denetimi. Uluslararası Türkçe Edebiyat Kültür Eğitim Dergisi, 5/2, 908-926.

Akyol, B. \& Akçay, R. C. (2015). Türkiye'deki örgütsel davranış çalışmalarının analizi. Eğitimde Kuram ve Uygulama, 11/1, 149-170.

Alkan, D.P. \& Arıkboğa, F. Ş. (2017). Etik liderlik ve örgütsel vatandaşlık davranışı ilişkisinde örgütsel özdeşleşmenin aracılık etkisi ve bir Uygulama. Yönetim ve Ekonomi, 24/2, 349-369

Arslantaş, C.C. \& Dursun, M. (2008). Etik liderlik davranışının yöneticiye duyulan güven ve psikolojik güçlendirme üzerindeki etkisinde etkileşim adaletinin dolaylı rolü. Anadolu Üniversitesi Sosyal Bilimler Dergisi, 8/1, 111-128

Aydın, T. (2010). İlköğretim okul yöneticilerinin etik liderlik özellikleri ile ilgili ögretmen görüşlerinin incelenmesi (Unpublished master thesis). Maltepe Üniversitesi, İstanbul.

Ayık, A., Yücel, E. \& Savaş, M., (2014). Öğretmenlerin örgütsel adalet algılarının yordayıcısı olarak okul yöneticilerinin etik liderlik davranışları. Abant İzzet Baysal Üniversitesi Eğitim Fakültesi Dergisi, 14/ 2, 233-252.

Balcı, A. \& Apaydın, Ç. (2009). Türkiye'de eğitim yönetimi araştırmalarının durumu: Kuram ve uygulamada eğitim yönetimi dergisi örneği. Kuram ve Uygulamada Ĕ̆itim Yönetimi, 15/59, 325-343.

Baştuğ, İ. (2009). Illköğretim okulu müdürlerinin etik liderlik davranışlarına ilişkin ögretmen görüşleri (Konya ili örneği) (Unpublihed master thesis) Selçuk Üniversitesi, Konya.

Birinci, G., Kılıçer K., Ünlüer, S. \& Kabakçı, I. (2009). Eğitim teknolojisi alanında yapılan durum çalışması araştırmalarının yöntemsel değerlendirilmesi. III. Uluslararası Bilgisayar ve Ögretim Teknolojileri Sempozyumu. Karadeniz Teknik Üniversitesi, Trabzon.

Brown M. E., Trevino L. K. \& Harrison D.A. (2005). Ethical leadership: a social learning perspective for construct development and testing. Organizational Behavior and Human Decision Processes, 97/2, 117-134.

Büyüköztürk, Ş, Çakmak, E. K., Akgün, Ö. E., Karadeniz, Ş. \& Demirel, F. (2012). Bilimsel araştırma yöntemleri. Ankara: Pegem A. 
De Hoogh, A.H. B. \& Den Hartog, D. (2008). Ethical and despotic leadership, relationships with leader's social responsibility, top management team effectiveness and subordinate's optimism: a multi method study. The Leadership Quarterly, 19/1, 297311. DOI: http://dx.doi.org/10.1016/j.leaqua.2008.03.002

Dedeoğlu, B.B., Çelik, S.,. İnan1, A. \& Alta, H. (2016). Etik liderlik, örgütsel bağlılık ve iş tatmini arasındaki ilişkide: cinsiyet ve çalışma süresinin farklılaştırıcı (moderate) rolü. Yönetim ve Ekonomi Araştırmalart Dergisi, 14/4, 45-70. DOI: http://dx.doi.org/10.11611/yead.282215 45.

Eisenbeiss, S. A. (2012). Re-thinking ethical leadership: an interdisciplinary integrative approach. Leadership Quarterly, 23/5, 791-808.

Eroğluer K. \& Yılmaz, Ö. (2015). Etik liderlik davranışlarının algılanan örgüt iklimi üzerine etkisine yönelik bir uygulama: İş yaşamında yalnızlık duygusunun aracılık etkisi. İsletme Araştırmaları Dergisi, 7/1, 280-308

Fraenkel, J.R. \& Wallen, N. (2005). How to design and evaluate research in education. New York: Mc Graw Hill.

Goodwin, L. D. \& Goodwin, W. L. (1985). Statistical techniques in AERJ articles, 1979-1983: The preparation of graduate students to read educational research literature. Educational Researcher, 14/2, 5-11.

Gül, H. \& İnce, M. (2014). Etik liderlik ve örgütsel adalet arasındaki ilişkiler üzerine bir araştırma. Niğde Üniversitesi İktisadi ve İdari Bilimler Fakültesi Dergisi, 7/2, 127-150.

Gültekin, M. (2008). Illköğretim okulu yöneticilerinin etik liderlik davranışı gösterme düzeylerinin çeşitli değişkenler açısından incelenmesi (Unpublished master thesis). Selçuk Üniversitesi, Konya.

Hermond, D. (2005). Ethical leadership is not optional: how LPPs can help. International Journal of Scholarly Academic Intellectual Diversity-Electronic, 8/1, 1-5.

İşçi, S. (2013). Türkiye'de ĕgitim yönetimi alanında yapılmış lisansüstü tezlerin tematik, metodolojik ve istatistiksel açıdan incelenmesi (Yayımlanmamış yüksek lisans tezi). (Unpublished master thesis). Eskişehir Osmangazi Üniversitesi, Eskişehir.

Kalyar, M. N. (2017). Psikolojik sermaye, lider-üye etkileşimi ve motivasyon ara değişkenleri bağlamında etik liderliğin yaratıcılık ve performans üzerindeki etkisi. (Unpublished doctoral dissertations). İnönü Üniversitesi, Malatya.

Karadağ, E. (2009). Türkiye'de ĕğitim bilimleri alanında yapılmış doktora tezlerinin tematik ve metodolojik açıdan incelemesi: bir durum çalışması (Unpublished doctoral dissertations). Marmara Üniversitesi, İstanbul.

Karasar, N. (2014). Bilimsel araştırma yöntemleri. Ankara: Nobel

Kütükcü, A. (2017). Türkiye'de kadın liderlik alanında yapılan lisansüstü tezlerin incelenmesi. İstanbul Üniversitesi Kadın Araştırmalarl Dergisi, 15/2, 26-47. 
Okçu, V. (2014). Ortaöğretim okulu yöneticilerinin etik liderlik davranışları ile öğretmenlerin örgütsel bağlılıkları arasındaki ilişki. Kuram ve Uygulamada Eğitim Yönetimi (Educational Administration: Theory and Practice), 20/4, 501-524. DOI: doi.10.14527/kuey.2014.020.

Onwuegbuzie, A. J. (2002). Common methodological, analytical and interpretational errors in published educational studies: An analysis of the 1998 volume of the British journal of educational psychology. Educational Research Quarterly, 26/1, 11-22.

Özdemir, A. (2015). Öğretmenlerin okullarına duygusal bağl1lıklarının müdürlerin sosyal becerileri, kullandıkları güç kaynakları ve etik liderlik davranışları açısından incelenmesi. GEFAD / GUJGEF 35/3, 595-618.

Pehlivan, İ. (1999). Eğitim yöneticilerinin etik davranışları üzerine bir araştırma (Ankara ili örneği). IV. Ulusal Eğitim Bilimleri Kongresi Bildirileri, Eskişehir: Anadolu Üniversitesi Yayınları.

Resick, C.J., Hanges, P. J, Dickson, M.W \& Michelson, J. K. (2006). A cross-cultural examination of the endorsement of ethical leadership, Journal of Business Ethics, 63 /4, 345-359.

Sergiovanni, T. (2015). Ahlaki Liderlik: Okul gelişiminin özüne inmek (S. Kıranl1Güngör, Trans.) Ankara: Nobel.

Stevenson, J. (2000). Seven years of vocational education research: a review of material published in the Australian and New Zealand journal of vocational education research. Australian and New Zealand Journal of Educational Research, 8/1, 93-113.

Stouten, J., Van Dijke, M .\& De Cremer, D. (2012). Ethical leadership: an overview and future perspectives (editorial). Journal of Personnel Psychology, 11/1, 1-6.

Strang, S. E. (2004). Big five personality and leadership developmental levels as predictors of leader performance (A Thesis Submitted to the Graduate Faculty of The University of Georgia in Partial Fulfillment of the Requirements for the Degree Master of Science). B.S., The University of Georgia.

Şentürk, F. K. (2014). Etik liderliğin belirleyicileri olarak kişilik, örgüt kültürü, dini yönelim ve çevresel faktörler: Antalya'daki dört ve beş ylldızl otellerde bir uygulama (Unpublished doctoral dissertations). Akdeniz Üniversitesi, Antalya.

Şimşek, Y. \& Altınkurt, Y. (2009). Okul müdürlerinin etik liderlik uygulamalarına ilişkin öğretmen görüşleri. I. Uluslar Arası Eğitim Araştırmaları Kongresi, Bildirileri, Tam metin. Retrieved from oc.eab.org.tr/egtconf/pdfkitap/indexb.php?

Thoms, J.C. (2008). Ethical integrity in leadership and organizational moral culture, . Sage Publications (Los Angeles, London, New Delhi, and Singapore), 4/4, 419-442. DOI: doi/pdf/10.1177/1742715008095189. 
Topuzoğlu, A. P. (2009). Demografik özellikler açısından okul yöneticisinin etik liderlik özellikleri- İstanbul ili Anadolu yakası örneği (Unpublished mater thesis). Maltepe Üniversitesi, İstanbul.

Turhan M. (2007.) Genel ve mesleki lise yöneticilerinin etik liderlik davranışlarının okullardaki sosyal adalet üzerindeki etkisi (Unpublished doctoral dissertations). Firat Üniversitesi, Elazığ.

Uğurlu, C. T. (2009). İlköğretim okulu öğretmenlerinin örgütsel bağllllk düzeylerine yöneticilerin etik liderlik ve örgütsel adalet davranışlarının etkisi (Unpublished doctoral dissertations). İnönü Üniversitesi, Malatya.

Uysal, Ş. (2013). Türkiye'de eğitim yönetimi teftişi planlaması ve ekonomisi alanındaki doktora tezlerinin içerik analizi (Unpublished doctoral dissertations). Eskişehir Osmangazi Üniversitesi, Eskişehir.

Varışoğlu, B., Şahin, A. \& Göktaş, Y. (2013). Türkçe eğitim araştırmalarında eğilimler. Kuram ve Uygulamada Eğitim Bilimleri, 13/3, 1767-1781. DOI: 10.12738/estp.2013.3.1609.

Yıldırım, A. \& Şimşek, H. (2016). Sosyal bilimlerde nitel araştırma yöntemleri. Ankara: Seçkin.

Yıldırım, A. (2010). Etik liderlik ve örgütsel adalet ilişsisi üzerine bir uygulama (Unpublished master thesis). Karamanoğlu Mehmetbey Üniversitesi, Karaman.

Yıldız, B. (2016). Mesleki ve teknik Anadolu liseleri okul müdürlerinin etik liderlik davranışları gösterme düzeylerinin incelenmesi (Bursa ili Gemlik ilçesi örneği) (Unpublished master thesis). Yeditepe Üniversitesi, İstanbul.

Yılmaz, E. (2005). Etik liderlik ölçeğinin geçerlik ve güvenirlik çalışması. XIV. Ulusal Eğitim Bilimleri Kongresi, 28-30 Eylül, Denizli.

Yılmaz, E. (2006). Okullardaki örgütsel güven düzeyinin okul yöneticilerinin etik liderlik özellikleri ve bazı değişkenler açısından incelenmesi (Unpublished doctoral dissertations). Selçuk Üniversitesi Sosyal Bilimler Enstitüsü, Konya.

Yukl, G., Mahsud, R., Hassan, S. \& Prussia, G. E. (2013). An imrpoved measure of ethical leadership. Journal of Leadership and Organizational Studies, 20/1, 38-48. DOI: doi/abs/10.1177/1548051811429352.

Zhu, W., May, D.R.,\& Avolio, B.J. (2004). The impact of ethical leadership behavior on employee out comes: The roles of psychological empowerment and authenticity. Journal of Leadership and Organizational Studies, 11/1, 16-26

Aris, B., Yahaya, N., Harun, J., \& Tasir, Z. (2000). Education Technology. Skudai: University of Teknologi Malaysia.

Azhar M. (2007) Level Of Professionalisme Among Islamic Education Trainees In Practical Teaching, unpublished Masters thesis, Universiti Teknologi Malaysia, retrieved September 2011 from eprints.utm.my/4276/1/75215.pdf 